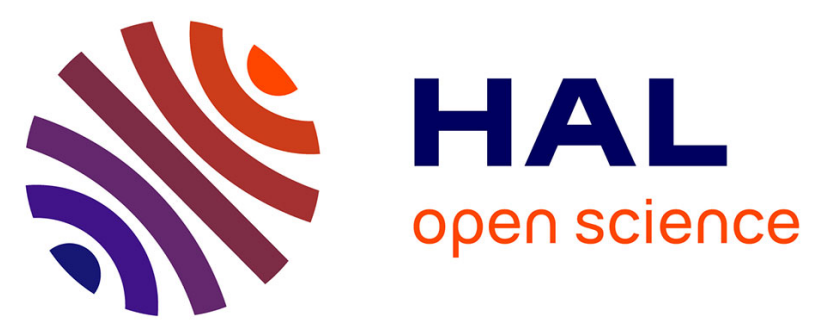

\title{
Increasing species and trophic diversity of mesofauna affects fungal biomass, mesofauna community structure and organic matter decomposition processes
}

\author{
Jérôme Cortet, Richard Joffre, Susanne Elmholt, Paul Henning Krogh
}

\section{- To cite this version:}

Jérôme Cortet, Richard Joffre, Susanne Elmholt, Paul Henning Krogh. Increasing species and trophic diversity of mesofauna affects fungal biomass, mesofauna community structure and organic matter decomposition processes. Biology and Fertility of Soils, 2003, 37 (5), pp.302-312. 10.1007/s00374003-0597-2 . hal-03218658

\section{HAL Id: hal-03218658 \\ https://hal.science/hal-03218658}

Submitted on 5 May 2021

HAL is a multi-disciplinary open access archive for the deposit and dissemination of scientific research documents, whether they are published or not. The documents may come from teaching and research institutions in France or abroad, or from public or private research centers.
L'archive ouverte pluridisciplinaire HAL, est destinée au dépôt et à la diffusion de documents scientifiques de niveau recherche, publiés ou non, émanant des établissements d'enseignement et de recherche français ou étrangers, des laboratoires publics ou privés. 
Jérôme Cortet • Richard Joffre · Susanne Elmholt •

Paul Henning Krogh

\section{Increasing species and trophic diversity of mesofauna affects fungal biomass, mesofauna community structure and organic matter decomposition processes}

\begin{abstract}
A laboratory mesocosm experiment was set up to study the effects of five mesofauna model communities on litter fungal biomass (ergosterol content) and litter decomposition parameters (litter mass remaining, $\mathrm{N}$ concentration) for 4 months. The five treatments were: (1) no soil mesofauna, (2) the collembolan Folsomia fimetaria, (3) an assemblage of the collembolan species Isotomurus prasinus, Hypogastrura assimilis, F. fimetaria, Mesaphorura macrochaeta and Protaphorura armata, (4) the same collembolan assemblage plus the enchytraeid Enchytraeus crypticus, and (5) the six species plus the predaceous mite Hypoaspis aculeifer. After 30, 60, 90 and 120 days of incubation, six mesocosms of each treatment were sacrificed and biomass, species richness and dominance were measured. Changes occurred during the study with an increase in total detritivore biomass and a decrease in species richness with strong dominance by a few species in multispecies mesocosms. A vertical stratification of species was also observed in the mesocosms. Litter mass loss and $\mathrm{N}$ mineralisation were reduced with the introduction of fauna and showed the largest effects in the multispecies detritivore treatments. Ergosterol production was only temporary reduced in the multispecies treatments reflecting an effect of mesofauna on fungal biomass related to diversity rather than the biomass of mesofauna. An inhibitory predator effect was observed on functional decomposition parameters and indicated top-down control of decomposition via detritivorous mesofauna.
\end{abstract}

Keywords Decomposition - Ergosterol $\cdot$ Mesofauna community structure $\cdot$ Nitrogen

\section{Introduction}

In recent years, several studies have focused on the relations between the structure of communities and the functioning of ecosystems (Hector et al 1999; Huston et al 2000). However, few studies have concentrated on relations between soil fauna community structure and soil functioning. This is an interesting issue, as organic matter decomposition and nutrient recycling are regulated by: (1) the physico-chemical environment in which decay takes place, and (2) the resource quality, acting through the decomposer organisms (Joffre and Ågren 2001; Lavelle et al. 1993). These decomposers are primarily represented by microflora (bacteria and fungi), macrofauna (especially earthworms and diplopods), mesofauna (mainly microarthropods such as Collembola and acarids, and enchytraeids) and microfauna (nematodes and Protozoa). In this context, the importance of interactions between the soil mesofauna and the microbial community on decomposition processes remains one of the key issues in ecology (Wardle and Giller 1996, Wardle and Lavelle 1997). The action of mesofauna detritivores is usually considered indirect as they mainly feed on bacteria and fungi, even if some species can also feed directly on organic matter (Hopkin 1997). Siepel and Maaskamp (1994) suggested that three factors influence microbial respiration (and thus indirectly decomposition) when microbes are grazed by microarthropods: (1) the nature of 
grazing (herbivorous grazing, herbofungivorous grazing, fungivorous grazing or fungivorous browsing), (2) the density of microarthropods, and (3) the nutrient content of the substrate. The importance of mesofauna abundance has been documented, as several authors have observed decreasing effects on nutrient turnover with increasing abundance. Thus, Theenhaus et al. (1999) observed a negative effect of two collembolan species on slug cast decomposition at high densities, but no significant differences at low densities. Even though herbivory is not a linear response, these results seem to be the consequence of overgrazing that often occurs under laboratory conditions (Mebes and Filser 1998; Setälä et al. 1988; Verhoef 1996).

On the other hand, some predators can also indirectly affect decomposition activity by feeding on detritivores and thus decrease their pressure on microorganisms. Hedlund and Sjögren-Öhrn (2000) demonstrated that predators could increase the respiration rate in soil microcosms compared to microcosms containing only fungi or fungi plus species of Collembola. Studies like this usually concentrate on whether the control of food chains is top-down or bottom-up. But results of different studies often appear contradictory (Hedlund and SjögrenÖhrn 2000; Mikola and Setälä 1998a).

Most of the studies have concentrated on abundance or biomass effects of mesofauna, although some authors noted the importance of species richness or diversity (Mebes and Filser 1998; Setälä et al. 1991) for decomposition processes. For instance, the various microbivorous species can have feeding preferences for particular fungi and/or bacteria or be very generalist feeders (Booth and Anderson 1979; Chen et al. 1995; Verhoef et al. 1988). Predation can also be more or less selective and modify microbivore abundance and finally have an indirect cascade effect on activity of microorganisms (Christiansen 1971).

We hypothesize that mesofauna species richness could have a measurable effect on decomposition processes. To test this hypothesis, we conducted laboratory decomposition experiments involving five levels of species richness to investigate the dynamics of the mesofauna species involved and the effects on fungal biomass, organic matter decomposition and $\mathrm{N}$ mineralisation.

\section{Materials and methods}

For practical reasons at the initiation of the experiments mesocosms were divided into six series comprising all the diversity treatments. A total of 120 microcosms were initiated corresponding to five treatments, four study dates and six replicates. The series were initiated over a period of 4 weeks. At each sampling date and for each treatment, six mesocosms were randomly collected and sacrificed for analyses.

\section{Diversity treatment levels}

Five different diversity levels were chosen, including from one to three trophic levels among mesofauna:
1. Microflora-microfauna only, where mesocosms contained fungi and bacteria and then Protozoa and nematodes but no mesofauna, represented by only one type of mesocosm (MIC), which measures effects of microbial activity without any grazing or predation by mesofauna.

2. Detritivorous, with three types of mesofauna combinations. One measured the effects of the collembolan Folsomia fimetaria in combination with microflora and microfauna (FF); another examined five collembolan species (Isotomurus prasinus, Hypogastrura assimilis, F. fimetaria, Mesaphorura macrochaeta and Protaphorura armata) which have different ecological niches, in combination with microflora and microfauna (COL); adding an enchytraeid (Enchytraeus crypticus) to the COL assembly created the third treatment (DET). Most of these species are usually considered to be fungal feeders, although some omnivory cannot be excluded.

3. Predator, with the introduction of the predaceous mite Hypoaspis aculeifer into the most complex detritivorous system DET (PRED). Hypoaspis aculeifer has been shown to feed on different Collembola species (Krogh 1995).

F. fimetaria, M. macrochaeta, $P$. armata, $H$. assimilis, E. crypticus and $H$. aculeifer were collected from existing laboratory cultures. I. prasinus was collected from the field by extraction of litter samples under light and transferred to Petri dishes.

\section{Preparation of containers}

Mesocosms were contained in cylinders. The soil was a sandy loam collected at Askov (south Jutland, Denmark). The soil was defaunated by alternate drying and freezing (Krogh 1995). The soil was sieved (2-mm mesh) then $2.6 \mathrm{~kg}$ soil corresponding to 1.21 was transferred into each container and moistened with water to $15 \%$ (dry weight basis). Wheat straw litter (initial $\mathrm{C} / \mathrm{N}=168$ ), added as organic matter substrate, was cut into pieces of 5-10 cm; $4.0 \mathrm{~g}$ were weighed for each mesocosm, put into paper bags and dried at $60^{\circ} \mathrm{C}$ for $24 \mathrm{~h}$. A $1-\mathrm{mm}$ mesh was put on the topsoil. Litter was put on the mesh and moistened with $15 \mathrm{ml}$ water. All containers were inoculated with a soil extract to stimulate microbial activity. The soil extraction was prepared by mixing and gently shaking $100 \mathrm{~g}$ fresh Askov soil with 11 water. After 1 night of decanting, 0.51 of the supernatant was filtered through a $10-\mu \mathrm{m}$ mesh (Huhta et al. 1989). The filtrate was diluted to 11 with water and then $30 \mathrm{ml}$ of this suspension was sprayed on the wheat straw litter of each mesocosm. Containers were then weighed and transferred to a $20^{\circ} \mathrm{C}$ room for $48 \mathrm{~h}$ before animal addition. Twenty individuals of each of the species, F. fimetaria, M. macrochaeta, $I$. prasinus and $H$. assimilis, ten individuals of $P$. armata and 40 individuals of $E$. crypticus were added to the corresponding mesocosms (depending on the treatment). Twenty sexually mature $H$. aculeifer (ten males and ten females) were added to PRED mesocosms $48 \mathrm{~h}$ after adding detritivores. These numbers of individuals were estimated to be minimum numbers necessary to obtain a viable and reproductive population for each species in the mesocosms. After animal addition, mesocosms were weighed and moisture was adjusted weekly by spraying water onto the litter to maintain approximately $15 \%$ soil water content. Each mesocosm was covered by a transparent plastic lid with holes for ventilation. Containers were stored at $15^{\circ} \mathrm{C}$ with a $12 \mathrm{~h}$ periodic lightning before sampling.

\section{Mesofauna extraction and evaluation}

Microarthropods were extracted from the litter under a $60 \mathrm{~W}$ light for 2 days and into a benzoic acid solution $(2.9 \mathrm{~g} / \mathrm{l})$. After extraction, the wheat litter was stored at $-18^{\circ} \mathrm{C}$. Furthermore, mesofauna was extracted from the "top" $0-1 \mathrm{~cm}$ of upper soil and the "bottom" 1$4 \mathrm{~cm}$. After separation of the two layers, the soil was gently homogenised and a weighed subsample (200 g fresh soil) was sampled from each layer. Microarthropods were then extracted from the soil using a high gradient extractor (MacFadyen type, Takeda 
1979). After extraction from soil and litter, animals were conserved in glycerol and counted under a binocular microscope. The lengths of randomly selected representatives of each species from each layer and each sampling date were measured under the microscope. Then, lengths were transformed into biomass by using equations derived from laboratory measurements (Petersen 1975). Predatory mite biomass was estimated by using data from the literature (Petersen and Luxton 1982). Enchytraeids were extracted from the two soil layers by flotation in water of a 70-g fresh soil subsample. They were then counted under a binocular microscope. Biomass was estimated as reported by Petersen and Luxton (1982). As it was not possible to pick out representative subsamples from the litter layer for enchytraeid extraction without disturbing litter microarthropod extraction, enchytraeids were not extracted from the litter. Biomass was expressed by mean total biomass of individuals per mesocosm (or soil for enchytraeids) or by total biomass $/ \mathrm{cm}^{2}$ (for layers comparisons). The mean number of species for each treatment expressed species richness $(R)$. Dominance was calculated with the Shannon evenness index $\left(H^{\prime}{ }_{x} / H_{\max }\right)$. These two indices $\left(R\right.$ and $\left.H^{\prime}{ }_{x} / H_{\max }\right)$ were calculated for detritivorous arthropods (only Collembola) and for detritivorous mesofauna (Collembola and enchytraeids), in order to estimate the stability of the soil fauna community during the study.

\section{Spectral and chemical analysis}

Litter mass remaining (LMR), $\mathrm{N}$ and ergosterol contents of the 120 litter samples were predicted from calibration equations derived from wet chemistry measurements performed on 50 representative samples in relation to the results of near-infrared spectrophotometry performed on the 120 samples. This cost effective and less destructive methodology compared to complete wet chemistry methods has been shown to be highly suitable for litter decomposition analysis (Cortet et al. 2002).

For this purpose, remaining litter samples were dried $(24 \mathrm{~h}$, $45^{\circ} \mathrm{C}$ ) and milled with a Cyclotec 1093 (1-mm mesh size). All the 120 samples were scanned with a near-infrared reflectance spectrophotometer (NIRS system 6500). Two replicate reflectance measurements of monochromatic light were made at 2-nm intervals over the range from 400 to $2,500 \mathrm{~nm}$ to produce an average spectrum with 1,050 data points. Reflectance $(R)$ was converted to absorbance $(A)$ using the following equation: $A=\log (1 / R)$. Data analysis was conducted using the ISI software system (Shenk and Westerhaus 1991a). The procedure SELECT of the ISI software was used to identify 50 representative samples to be analysed by wet chemistry. This procedure measures the standard Mahalanobis distances from each sample to every other sample and defines neighbourhoods in score space. The objective of SELECT is to identify one sample for every neighbourhood (Shenk and Westerhaus 1991a). The 50 representative samples and the initial wheat litter samples were analysed using wet chemistry. Ash residues representing the mineral part of the litter $\left(550^{\circ} \mathrm{C}\right.$ for $\left.3 \mathrm{~h}\right)$ and $\mathrm{N}$ concentration (Roboprep $\mathrm{C}$ and $\mathrm{N}$ analyser; PZZ Europa) were determined. In order to quantify fungal biomass, ergosterol, a specific component of fungi strongly correlated to biomass, was extracted and analysed from the litter samples by combining microwave-assisted extraction (Young 1995) and SPE extraction (Gessner and Schmitt 1996) as described by Jensen et al. (2000). In five of the samples chosen randomly within the 50 samples, three subsamples of $0.05 \mathrm{~g}$ were weighed into a $27-\mathrm{ml}$ glass tube to test the homogeneity of the ergosterol content within samples. These results were used to prepare the NIRS calibration equations, which were used to test the variability within samples. For the other 45 samples, one subsample was used for analysis. The litter was treated with $0.5 \mathrm{ml}$ of $2 \mathrm{M} \mathrm{NaOH}$ and $2 \mathrm{ml}$ methanol and tightly sealed with a Teflon-lined screw cap. Extraction was performed in a Miele microwave oven $(780 \mathrm{~W}, 35 \mathrm{~s})$ and the extracts were left to cool for exactly $15 \mathrm{~min}$. One millilitre of extract from each tube was passed through preconditioned (methanol followed by water) Oasis columns using gravity, washed with $1 \mathrm{ml}$ of $60 \%$ methanol and thoroughly dried under vacuum. Ergosterol was eluted into HPLC vials with $1 \mathrm{ml}$ of 2-propanol using gravity. The eluate was evaporated to dryness under $\mathrm{N}_{2}$ flow, redissolved in $1 \mathrm{ml}$ methanol and fivefold diluted in methanol. The HPLC system consisted of a ContraMetric 4100 gradient pump and a SpectroMonitor 3200 UV detector (LDC Analytical) equipped with an auto-injector with a 200- $\mu$ l sample loop. The detector was set at $282 \mathrm{~nm}$. The column was a $125 \mathrm{~mm} \times 4-\mathrm{mm}$ Lichrosphere $100 \mathrm{RP}-18$, protected by a $4 \times 4-\mathrm{mm} \mathrm{C}_{18}$ guard column, both from Merck. The system was run isocratically with $100 \%$ methanol at a flow rate of $1.25 \mathrm{ml} \mathrm{min}^{-1}$. All results are presented on a dry weight basis.

\section{Near infrared reflectance spectroscopy calibration}

Calibrations were developed for ash, $\mathrm{N}$ and ergosterol contents of litter. The calibration equations were calculated using the modified partial least squares regression method (Martens and Jensen 1982; Shenk and Westerhaus 1991b). Cross validation was used to estimate the optimal number of terms in the calibration to avoid overfitting. This consists of selecting three-quarters of the samples to develop the model and one-quarter for the prediction. The algorithm was repeated 4 times and all the residuals of the four predictions were pooled to provide a SE of cross validation (SECV) on independent samples. The minimum SECV determines the number of terms to be used. The final model was then recalculated with all the samples to obtain the SE of calibration (SEC). The NIRS predicted values were obtained with SECs of $0.81 \%$ for ash (mean value of analysed samples $=4.72 \%, n=49$ ), $0.04 \mu \mathrm{mol} / \mathrm{mg}$ for $\mathrm{N}$ (mean value of analysed samples $=0.41 \mu \mathrm{mol} / \mathrm{mg}$ of $\mathrm{N}, n=49$ ), and $48 \mu \mathrm{g} / \mathrm{g}$ for ergosterol (mean value of analysed samples $=271 \mu \mathrm{g} / \mathrm{g}$, $n=47$ ).

The ash-free LMR was then calculated for each sample using the following equation:

$\mathrm{LMR}_{i}=100 \cdot \frac{\mathrm{MD}_{i}}{\mathrm{MD}_{0}} \cdot \frac{100-\mathrm{AT}_{i}}{100-\mathrm{AT}_{0}}$

where $\mathrm{LMR}_{i}$ is percentage of remaining litter mass of sample $i$, $\mathrm{MD}_{i}$ is dry mass of sample $i, \mathrm{MD}_{0}$ is dry mass of initial sample $i$, $\mathrm{AT}_{i}$ is $\%$ total ash concentration of sample $i, \mathrm{AT}_{0}$ is $\%$ initial total ash concentration of sample $i$.

$T_{i}=100 \cdot \frac{\mathrm{NC}_{i}}{100-\mathrm{AT}_{i}}$

From estimated $\mathrm{N}$ and ash content of each sample, $\mathrm{N}$ concentration in organic matter can be calculated for each sample, where $T_{i}$ is $\% \mathrm{~N}$ concentration in organic matter for sample $i, \mathrm{NC}_{i}$ is $\mathrm{N}$ concentration in sample $i$.

\section{Statistics}

For biomass of each species and diversity (species richness and dominance), LMR, ergosterol and $\mathrm{N}$ contents of the litter, differences between treatment diversity levels, between vertical litter and soil layers, between sampling occasion and between replicates were evaluated, as well as interactions between these factors. We used three-way and two-way factorial ANOVA (StatView software). Means were compared by Fisher's test.

\section{Results}

\section{Mesofauna biomass}

The total biomass of Collembola in the mesocosms increased during the study, from 0 to 90 days, and then decreased (Fig. 1). After 30 days, a greater biomass was observed in the multispecies mesocosms (COL, DET and PRED) than in the single species one (FF). But after 60 days, biomass was greater in FF and DET compared to 
Fig. 1 Biomass dynamics of the different taxa present in the mesocosms. Differences between biodiversity treatments \{one-way ANOVA on 24 samples for total Collembola and Folsomia fimetaria $[F$. fimetar$i a$ in combination with microflora and microfauna $(F F) ; F$. fimetaria, Isotomurus prasinus, Hypogastrura assimilis, Mesaphorura macrochaeta, Protaphorura armata in combination with microflora and microfauna $(C O L)$; COL plus Enchytraeus crypticus (DET), DET plus predaceous mite $H y$ poaspis aculeifer (PRED)], on 18 samples for $H$. assimilis, $I$. prasinus, M. macrochaeta and $P$. armata (COL, DET, PRED), on 12 samples for E. crypticus (DET, PRED), Fisher's test, $P<0.05\}$ are expressed by different letters at each sampling occasion
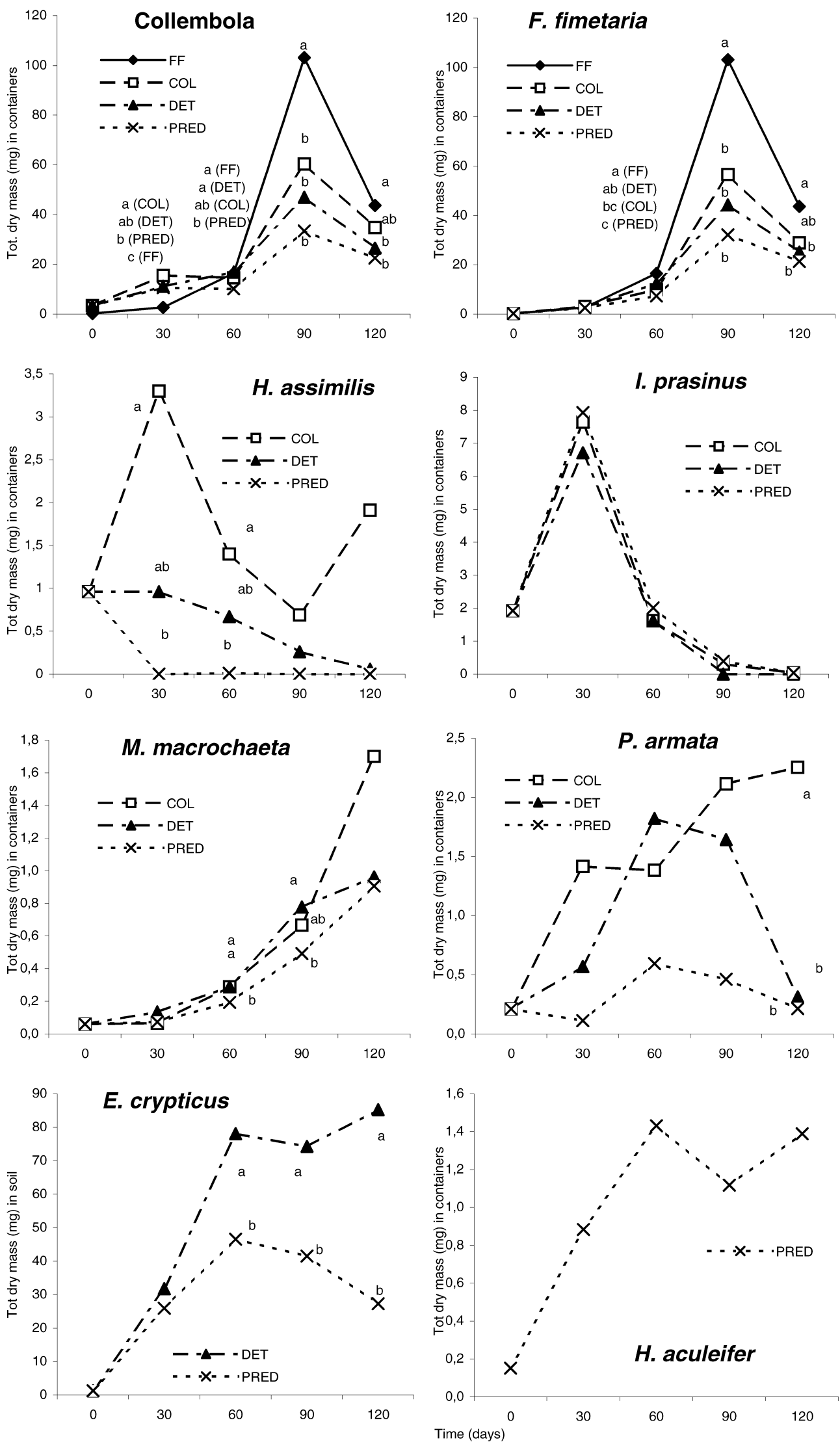
Table 1 Mean dry biomass and SE $\left(\mu \mathrm{g} / \mathrm{cm}^{2}\right)$ for each sampling date and each layer across the biodiversity treatments, with results of two-way ANOVA (diversity treatments $\times$ layer). For differences between biodiversity levels see Fig. 2. Differences between layers are expressed by different letters. NE No evaluation performed

\begin{tabular}{|c|c|c|c|c|c|c|c|}
\hline & Days & Litter & Topsoil & $\begin{array}{l}\text { Bottom } \\
\text { soil layer }\end{array}$ & $\begin{array}{l}\text { Biodi- } \\
\text { versity }\end{array}$ & Layer & $\begin{array}{l}\text { Biodiversity } \times \\
\text { layer }\end{array}$ \\
\hline Total Collembola & $\begin{array}{r}30 \\
60 \\
90 \\
120\end{array}$ & $\begin{array}{c}17.1 \pm 2.6(\mathrm{a}) \\
40.0 \pm 3.4(\mathrm{a}) \\
87.5 \pm 12.2(\mathrm{~b}) \\
101.7 \pm 11.3(\mathrm{a})\end{array}$ & $\begin{array}{c}19.9 \pm 2.9 \text { (a) } \\
20.5 \pm 2.0(\mathrm{~b}) \\
138.0 \pm 18.3(\mathrm{a}) \\
39.6 \pm 3.9 \text { (b) }\end{array}$ & $\begin{array}{l}1.1 \pm 0.2(\mathrm{~b}) \\
1.9 \pm 0.2(\mathrm{c}) \\
4.2 \pm 0.6(\mathrm{c}) \\
3.7 \pm 0.5(\mathrm{c})\end{array}$ & $\begin{array}{l}* * * \\
* \\
* * * \\
* *\end{array}$ & $\begin{array}{l}* * * \\
* * * \\
* * * \\
* * *\end{array}$ & $\begin{array}{l}* * \\
\mathrm{NS} \\
* \\
* *\end{array}$ \\
\hline Folsomia fimetaria & $\begin{array}{r}30 \\
60 \\
90 \\
120\end{array}$ & $\begin{array}{c}1.9 \pm 0.2(\mathrm{~b}) \\
32.6 \pm 0.8(\mathrm{a}) \\
85.9 \pm 12.5(\mathrm{~b}) \\
100.3 \pm 11.7(\mathrm{a})\end{array}$ & $\begin{array}{c}6.1 \pm 0.6(\mathrm{a}) \\
16.2 \pm 1.7(\mathrm{~b}) \\
135.0 \pm 18.4(\mathrm{a}) \\
36.8 \pm 3.7(\mathrm{~b})\end{array}$ & $\begin{array}{l}0.6 \pm 0.1(\mathrm{c}) \\
1.4 \pm 0.2(\mathrm{c}) \\
3.3 \pm 0.6(\mathrm{c}) \\
2.6 \pm 0.4(\mathrm{c})\end{array}$ & $\begin{array}{l}\mathrm{NS} \\
* * \\
* * * \\
* *\end{array}$ & $\begin{array}{l}* * * \\
* * * \\
* * * \\
* * *\end{array}$ & $\begin{array}{l}\mathrm{NS} \\
\mathrm{NS} \\
* \\
*\end{array}$ \\
\hline Hypogastrura assimilis & $\begin{array}{r}30 \\
60 \\
90 \\
120\end{array}$ & $\begin{array}{l}2.2 \pm 0.7(\mathrm{ab}) \\
1.8 \pm 0.8(\mathrm{a}) \\
1.1 \pm 0.7(\mathrm{a}) \\
1.7 \pm 1.7(\mathrm{a})\end{array}$ & $\begin{array}{l}2.8 \pm 1.6(\mathrm{a}) \\
1.0 \pm 0.4(\mathrm{ab}) \\
0.4 \pm 0.2(\mathrm{a}) \\
0.5 \pm 0.5(\mathrm{a})\end{array}$ & $\begin{array}{c}0.2 \pm 0.1 \text { (b) } \\
0.1 \pm 0.1 \text { (b) } \\
0.01 \pm 0.007 \text { (a) } \\
0.2 \pm 0.2 \text { (a) }\end{array}$ & $\begin{array}{l}* \\
* \\
\text { NS } \\
\text { NS }\end{array}$ & $\begin{array}{l}\text { NS } \\
\text { NS } \\
\text { NS } \\
\text { NS }\end{array}$ & $\begin{array}{l}\text { NS } \\
\text { NS } \\
\text { NS } \\
\text { NS }\end{array}$ \\
\hline Isotomurus prasinus & $\begin{array}{r}30 \\
60 \\
90 \\
120\end{array}$ & $\begin{array}{l}18.0 \pm 2.2 \text { (a) } \\
7.9 \pm 0.8 \text { (a) } \\
0.8 \pm 0.3 \text { (a) } \\
0 \text { (a) }\end{array}$ & $\begin{array}{c}13.5 \pm 1.7(\mathrm{a}) \\
1.2 \pm 0.2(\mathrm{~b}) \\
0.3 \pm 0.2(\mathrm{ab}) \\
0.08 \pm 0.06(\mathrm{a})\end{array}$ & $\begin{array}{l}0.4 \pm 0.07(\mathrm{~b}) \\
0.2 \pm 0.03(\mathrm{~b}) \\
0.003 \pm 0.003(\mathrm{~b}) \\
0 \text { (a) }\end{array}$ & $\begin{array}{l}\text { NS } \\
\text { NS } \\
\text { NS } \\
\text { NS }\end{array}$ & $\begin{array}{l}* * * \\
* * * \\
\text { NS } \\
\text { NS }\end{array}$ & $\begin{array}{l}\text { NS } \\
\text { NS } \\
\text { NS } \\
\text { NS }\end{array}$ \\
\hline Protaphorura armata & $\begin{array}{r}30 \\
60 \\
90 \\
120\end{array}$ & $\begin{array}{c}0.03 \pm 0.008(\mathrm{~b}) \\
0.2 \pm 0.1(\mathrm{~b}) \\
0.2 \pm 0.1(\mathrm{~b}) \\
0.1 \pm 0.06(\mathrm{~b})\end{array}$ & $\begin{array}{l}2.0 \pm 0.9 \text { (a) } \\
3.5 \pm 1.4 \text { (a) } \\
3.0 \pm 1.2 \text { (a) } \\
2.5 \pm 1.2 \text { (a) }\end{array}$ & $\begin{array}{c}0.07 \pm 0.03(\mathrm{~b}) \\
0.1 \pm 0.04(\mathrm{~b}) \\
0.5 \pm 0.1(\mathrm{~b}) \\
0.1 \pm 0.05(\mathrm{~b})\end{array}$ & $\begin{array}{l}\text { NS } \\
\text { NS } \\
\text { NS } \\
*\end{array}$ & $\begin{array}{l}* \\
* * \\
* \\
* *\end{array}$ & $\begin{array}{l}\text { NS } \\
\text { NS } \\
\text { NS } \\
*\end{array}$ \\
\hline Enchytraeus crypticus & $\begin{array}{r}30 \\
60 \\
90 \\
120\end{array}$ & $\begin{array}{l}\mathrm{NE} \\
\mathrm{NE} \\
\mathrm{NE} \\
\mathrm{NE}\end{array}$ & $\begin{array}{r}23.4 \pm 3.2 \text { (a) } \\
53.9 \pm 6.7 \text { (a) } \\
33.8 \pm 7.3 \text { (a) } \\
44.08 \pm 8.9 \text { (a) }\end{array}$ & $\begin{array}{r}22.8 \pm 3.8 \text { (a) } \\
48.2 \pm 5.7 \text { (a) } \\
48.5 \pm 6.9 \text { (a) } \\
45.03 \pm 9.9 \text { (a) }\end{array}$ & $\begin{array}{l}\text { NS } \\
* * \\
* \\
* * *\end{array}$ & $\begin{array}{l}\text { NS } \\
\text { NS } \\
\text { NS } \\
\text { NS }\end{array}$ & $\begin{array}{l}\text { NS } \\
\text { NS } \\
\text { NS } \\
\text { NS }\end{array}$ \\
\hline Hypoaspis aculeifer & $\begin{array}{r}30 \\
60 \\
90 \\
120\end{array}$ & $\begin{array}{l}0.7 \pm 0.2(\mathrm{~b}) \\
0.6 \pm 0.2 \text { (b) } \\
0.8 \pm 0.2 \text { (b) } \\
0.8 \pm 0.1 \text { (b) }\end{array}$ & $\begin{array}{c}1.9 \pm 0.2(\mathrm{a}) \\
2.3 \pm 0.3(\mathrm{a}) \\
2.7 \pm 0.5(\mathrm{a}) \\
3.5 \pm 0.6(\mathrm{a})\end{array}$ & $\begin{array}{l}0.2 \pm 0.2(b) \\
0.6 \pm 0.1(b) \\
0.2 \pm 0.08(b) \\
0.2 \pm 0.05(b)\end{array}$ & $\begin{array}{l}\mathrm{NE} \\
\mathrm{NE} \\
\mathrm{NE} \\
\mathrm{NE}\end{array}$ & $\begin{array}{l}* * * \\
* * * \\
* * * \\
* * *\end{array}$ & $\begin{array}{l}\mathrm{NE} \\
\mathrm{NE} \\
\mathrm{NE} \\
\mathrm{NE}\end{array}$ \\
\hline
\end{tabular}

$* P<0.05, * * P<0,01, * * * P<0.0001, N S$ non-significant (Fisher's test)

Calculations have been performed on 72 samples (total Collembola and F. fimetaria), 54 samples (H. assimilis, I. prasinus, M. macrochaeta and P. armata) or 24 samples (E. crypticus). A one-way ANOVA of 18 samples was used for $H$. aculeifer (differences between soil layers)

PRED. Then, after 90 days, biomass was greater in FF compared to all other treatments (COL, DET, PRED). At the end of the experiment, total Collembola biomass was still greater in FF compared to DET and PRED.

Significant differences occurred between layers, with a greater biomass in the upper layers (litter or topsoil). A significant interaction between diversity treatments and vertical distribution was observed after 30, 90 and 120 days (Table 1). However, these interactions only reflected a greater difference between diversity treatments in the upper layers (litter and topsoil) compared to the lowest (bottom soil). Collembola species presented various biomass dynamics and vertical distribution. One increased during the study ( $M$. macrochaeta), others presented variable fluctuations ( $F$. fimetaria, $H$. assimilis and $P$. armata), and one had completely disappeared by the end of the study (I. prasinus). However, all the species were able to reproduce in the mesocosms at the beginning of the experiment (Fig. 1). F. fimetaria was by far the most abundant species and presented significant differences between diversity treatments. Usually, a greater biomass was observed in the FF containers compared to those of the multispecies treatments (COL, DET, PRED) (Fig. 1). On the other hand, biomass was always greater in the topsoil and litter compared to the bottom soil (Table 1). A significant interaction was also observed between diversity treatments and layers, but only reflecting greater differences in the upper layers. M. macrochaeta presented a significantly lower biomass in PRED compared to COL (after 60 days) and compared to DET (after 60 and 90 days) (Fig. 1). A greater biomass was always observed in the bottom soil compared to the upper layers, but no interaction between diversity treatments and vertical distribution was observed (Table 1). $H$. assimilis had a greater biomass in COL compared to PRED after 30 and 60 days (Fig. 1). A greater biomass was also observed after 30 days in the topsoil and after 60 days in the litter compared to the bottom soil, but no 
interaction between diversity treatments and vertical distribution was observed (Table 1). Biomass of $P$. armata was greater in COL compared to DET and PRED after 120 days (Fig. 1). Biomass was also always higher in the topsoil compared to litter and bottom soil (Table 1). An interaction between diversity and vertical distribution was observed after 120 days. This species presented also a significant interaction between diversity level and replicates that contributed to a decrease in the diversity effect. I. prasinus did not show any significant difference between diversity treatments (Fig. 1). Biomass was significantly greater in the topsoil after 30 days and in the litter after 60 and 90 days compared to the other layers (Table 1). No interaction was observed between diversity treatments and layers.

The biomass dynamic of the enchytraeid E. crypticus in the soil was different in DET, where the species always increased, compared to PRED, where the species increased from 30 to 60 days and then decreased. Furthermore, biomass was significantly greater in DET compared to PRED at 60, 90 and 120 days (Fig. 1). No significant differences occurred between soil layers and no interaction between diversity treatments and vertical distribution was observed.

The biomass of the predaceous mite $H$. aculeifer was variable during the study in PRED treatments, i.e. it ranged between 883 and $1,430 \mu \mathrm{g}$ per container, indicating that reproduction occurred in mesocosms, increasing the number of mites (Fig. 2). Significant differences occurred between the different layers with a greater biomass in the topsoil than in the litter and bottom soil (Table 1).

\section{Species richness and dominance}

Detritivore species richness decreased during the study in all the multispecies treatments (Fig. 2). However it was stable in DET from 30 to 60 days, as well as in PRED from 30 to 90 days. Significant differences appeared between treatments, with a greater species richness in DET compared to COL after 30,60 and 120 days and compared to PRED after 30 and 60 days. After 90 days PRED presented the greatest species richness with a significant difference compared to COL. The Shannon evenness index decreased from 30 to 120 days in all the multispecies mesocosms (Fig. 2). But the decrease was stronger in COL compared to DET and PRED, when taking into consideration all the detritivores. Thus, no differences between treatments were observed after 30 and 60 days, but then DET and PRED presented a significantly greater index compared to COL. These results can be explained by the strong dominance of $F$. fimetaria in the multispecies mesocosms, especially when I. prasinus disappeared (Fig. 2). However, in DET and PRED, E. crypticus, which presented a great abundance, contributed to an increase in the Shannon index. Thus, when considering only Collembola, no differences appeared between COL, DET and PRED.
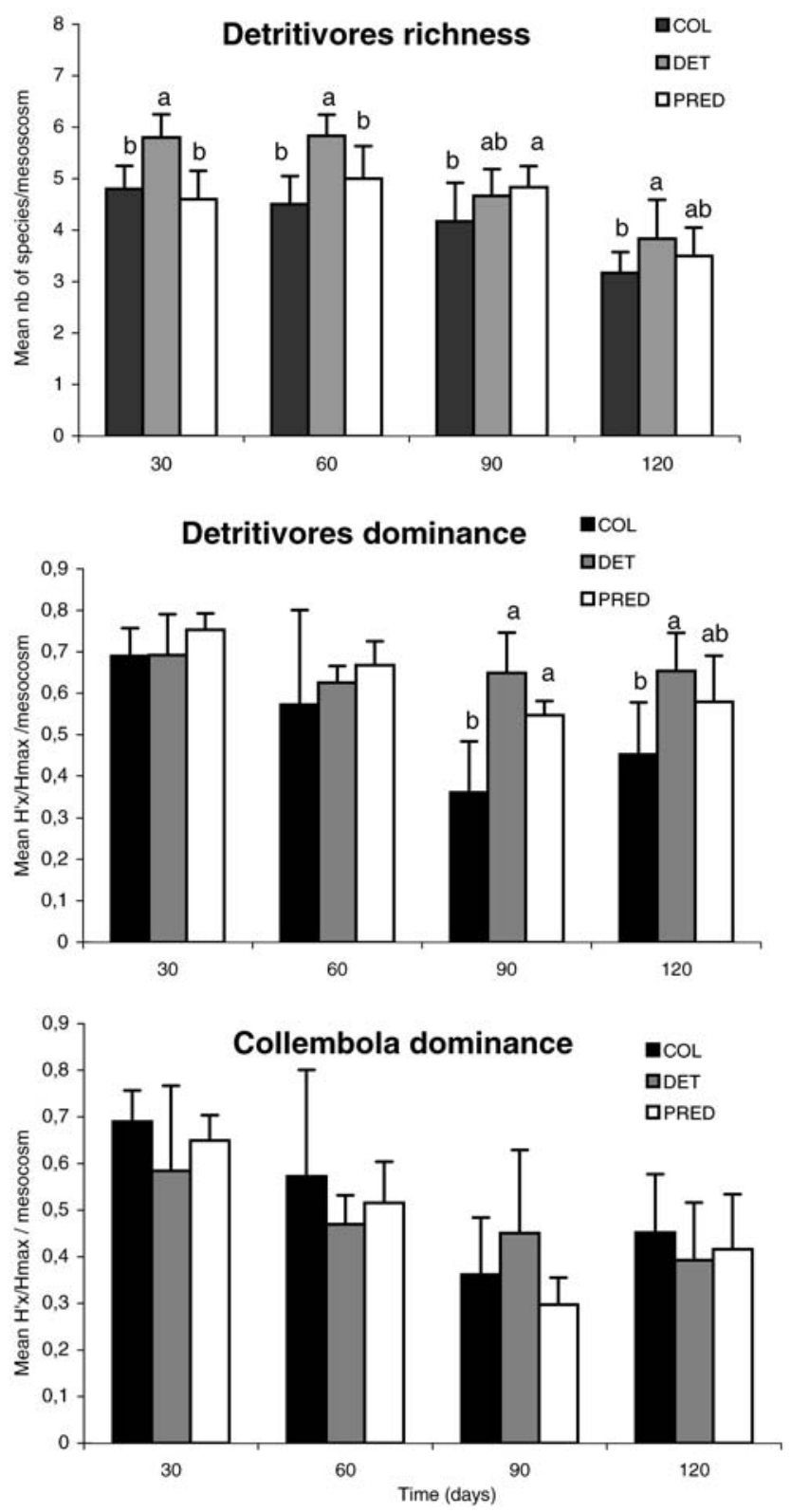

Fig. 2 Richness and dominance (Shannon evenness index $H^{\prime}{ }_{x}^{\prime}$ $\left.H_{\max }\right)$ of detritivores and Collembola in the containers. Significant differences (Fisher's test, $P<0.05$ ) are expressed by different letters at each sampling occasion [one-way ANOVA on 24 samples for richness (FF, COL, DET, PRED), 18 for dominance (COL, DET, PRED)]. For significance of treatments, see text. For abbreviations, see Fig. 1

\section{Ergosterol concentration}

From 0 to 30 days, ergosterol concentration in the litter increased in all the treatments (Fig. 3). Three different patterns could be observed on the following dates:

1. In MIC, an increase in concentrations was observed, with periods of relative stability (30-60 days and 90120 days); 
Fig. 3 Ergosterol, litter $\mathrm{N}$ and litter mass remaining $(L M R)$ at each sampling date and for each type of treatment. Significant differences (Fisher's test, $P<0.05)$ between treatments are expressed by different letters at each sampling occasion [oneway ANOVA, 28 samples (microflora and microfauna only $(M I C), \mathrm{FF}, \mathrm{COL}, \mathrm{DET}, \mathrm{PRED})]$. For other abbreviations, see Fig. 1
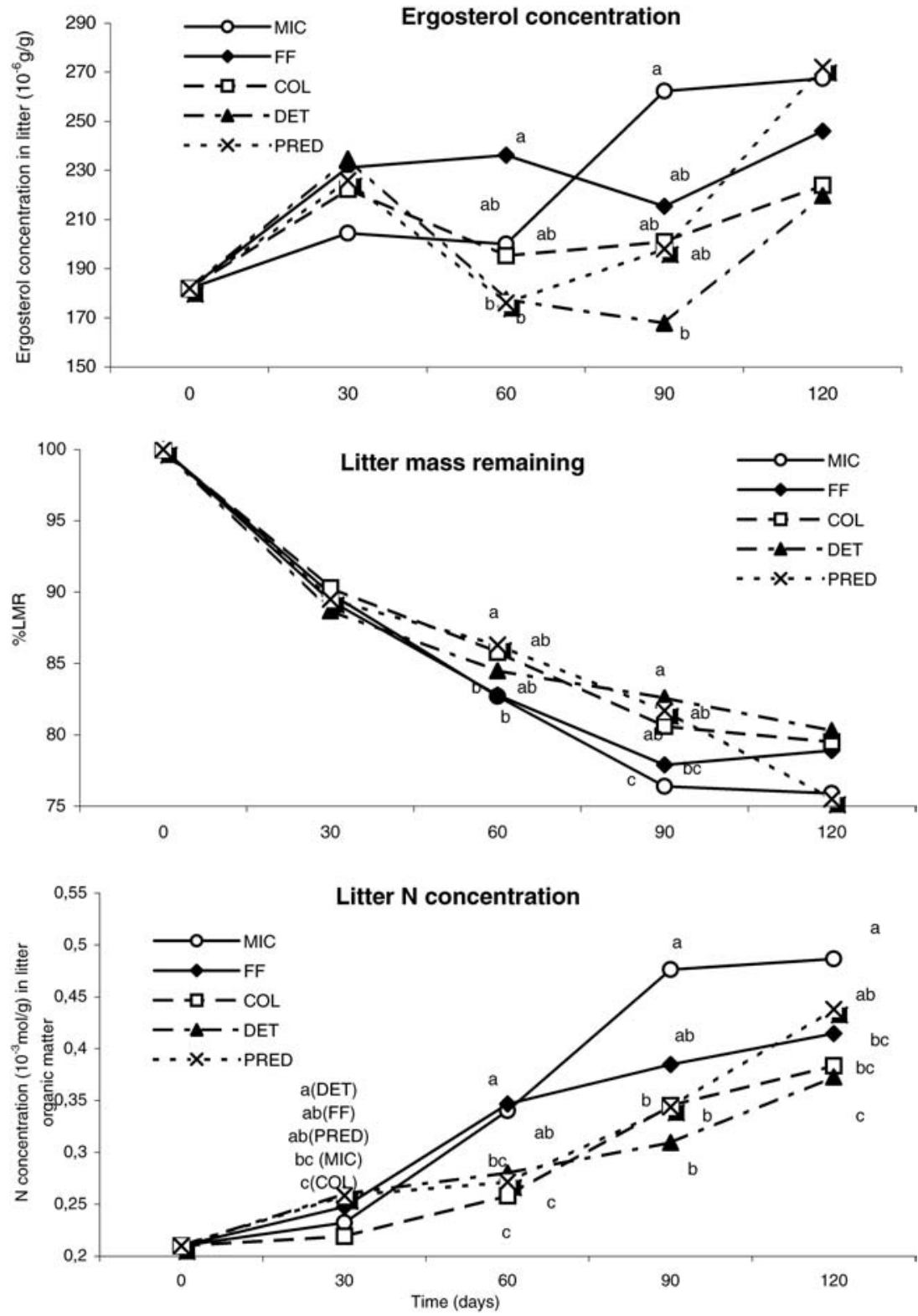

2. In FF, concentrations remained stable along the study with a slight decrease from 60 to 90 days, followed by a slight increase from 90 to 120 days;

3. In the multispecies treatments (COL, DET and PRED), a decrease was observed after 30 days followed by an increase. The decrease seemed less important in treatments with only collembolans compared to treatments containing enchytraeids. With predators the ergosterol decrease seemed smaller and the following increase faster than without.

However, these patterns were merely trends as the differences between multispecies mesocosms along the study were not significant.
Litter mass remaining

LMR decreased from 0 to 120 days in all the treatments (Fig. 3). At the end of the experiment, the percentage of LMR varied between $76 \%$ (MIC and PRED) and $80 \%$ (DET).

Decomposition was decreased in mesofauna treatments after 60 and 90 days, but significant differences occurred only between control treatments without fauna (MIC) and multispecies mesocosms. No differences were observed between MIC and FF. Furthermore, a significantly greater decomposition was observed in the singlespecies mesocosms compared to the multispecies mesocosms containing enchytraeids (with predators after 60 days, without predators after 90 days). No significant differences were found for the first and the last sampling occasions. 
$\mathrm{N}$ concentration in the litter

Litter $\mathrm{N}$ concentration increased in all the treatments (Fig. 3) reaching values ranging from 0.37 (DET) to $0.49 \mu \mathrm{mol} / \mathrm{mg}$ organic matter (MIC) after 120 days. Significant differences occurred but varied throughout the study. After 30 days, significant differences were noticed between treatments, with a greater $\mathrm{N}$ concentration in DET than in MIC and COL, and a greater $\mathrm{N}$ concentration in FF and PRED compared to COL. After 60 days, a significant effect of the fauna was observed with greater $\mathrm{N}$ concentrations in the treatments without fauna or with only one species compared to multispecies mesocosms. This effect was confirmed after 90 days. At the end of the experiment, the greatest $\mathrm{N}$ concentration was still observed in treatments without fauna, but a significant difference was also found between FF and MIC. Furthermore, the $\mathrm{N}$ concentration was increased in PRED.

\section{Discussion}

Mesofauna dynamics

Many of the observed changes in mesofauna biomass, richness and dominance within the different layers can be explained by species behaviour and interactions. After 30 days, total Collembola biomass was greater in multispecies than single species mesocosms, because all the introduced species were well represented in the multispecies containers. For example, species like $I$. prasinus, a typical epiedaphic species, well adapted to surface litter life, with eyes, a strong capacity for mobility, and sexual reproduction, had a high biomass in the multispecies containers at this sampling date. Our observations showed that a lot of young I. prasinus were present in the containers at this sampling date, indicating a good rate of reproduction at the beginning of the experiment. But then, the biomass of $F$. fimetaria, an euedaphic non-pigmented eyeless species that reproduces sexually, increased quickly especially in the single species containers, while total Collembola biomass only slightly increased in the multispecies mesocosms. These results should certainly indicate interspecific competition processes in the multispecies mesocosms limiting the development of several of the Collembola species. In fact the dominance of $F$. fimetaria became stronger throughout the study in the multispecies containers. A predation effect was also observed, as the lowest Collembola biomass was observed in the most diversified mesocosms containing the predaceous mite $H$. aculeifer, previously characterised as being polyphagous and having a hemiedaphic/euedaphic distribution (Sardar and Murphy 1987). Furthermore, several species presented significant differences between PRED and other multispecies treatments (COL and DET) indicating an effect of predation. Thus $H$. assimilis, an epi- to hemiedaphic species that reproduces sexually, as well as $P$. armata and $M$. macrochaeta, typically parthenogenetic euedaphic spe- cies, were significantly reduced in PRED at various sampling occasions. The enchytraeid species was also reduced by predation. Only I. prasinus seemed to slightly benefit from the introduction of $H$. aculeifer. This might have been due to decreased competition from other species combined with lower predation (I. prasinus is large and very mobile compared to the others and probably more difficult for mites to catch). Finally, after 120 days, total Collembola biomass still remained higher in the single species treatments compared to the others, even though a decrease was observed for all the treatments. This decrease, essentially due to $F$. fimetaria, could be due to the physically limiting capacity of containers, increasing the intraspecific competition. However, other species like M. macrochaeta and E. crypticus continued to increase in the multispecies mesocosms. These are typically endogeic species, and thus probably less limited by competition with $F$. fimetaria, as this last species is significantly more abundant in the upper layers. Thus, depth certainly had an influence on species dynamics, and species whose biomass were highly decreased were almost epigeic (I. prasinus, $H$. assimilis).

Relations between mesofauna, fungal biomass and litter decomposition processes

Ergosterol is a fungal cell wall constituent, used as a measure of dead and alive fungi. Though widely accepted as an indicator of total fungal biomass, the use of ergosterol has been questioned because some fungi cannot produce this compound and concentrations vary both within and between species (Djajakirana et al. 1996; Mercer 1984). Moreover, the ergosterol content depends to some extent on the physiological state of the fungus (Bermingham et al. 1995). On the other hand ergosterol is an indicator of fungal biomass rather than fungal activity. Thus Vedder et al. (1996) concluded that fauna contributed to an increase in microbial activity but did not increase microbial biomass. Mikola and Setälä (1998b) have also shown that bacteria grazed by bacterivorous nematodes compensate for consumed biomass by increasing their turnover rates. Despite these reservations, ergosterol is widely regarded as one of the most convenient indicators of fungal biomass in soil (Möttönen et al. 1999, Pasanen et al. 1999, Stahl and Parkin 1996). During the course of the experiment, ergosterol concentrations increased from levels of about $182 \mu \mathrm{g} / \mathrm{g}$ litter at the beginning to $267 \mu \mathrm{g} / \mathrm{g}$ litter at the two last samplings in the mesocosm with only one trophic level (MIC). This increase is correlated with the largest decrease in LMR in MIC, indicating that fungi were using the straw as a nutrient resource for growth, an ability many fungal species are known to possess (Domsch and Gam 1993). By adding grazing species to the mesocosms it clearly appeared that the mesofauna had a negative impact on ergosterol quantity, i.e. on fungal biomass. The mesofauna had a negative impact on functional decomposition parameters too, with a decrease in $\mathrm{N}$ mineralisation and 
litter decomposition. This last effect has been commonly observed in microcosm experiments. It is usually suggested that mesofauna decrease microflora activity by consumption of fungi and/or bacteria at high mesofauna population densities (Hanlon and Anderson 1979; Hedlund and Sjögren-Öhrn 2000).

Ergosterol contents and functional decomposition parameters are more affected in multispecies detritivorous fauna treatments compared to single species treatments. Even though differences between COL and DET are difficult to interpret, as the biomass of enchytraeids was not evaluated in the litter layer, differences between FF and $\mathrm{COL}$, concerning particularly $\mathrm{N}$ concentrations in organic matter, suggest that functional decomposition parameters are influenced by species richness and not only by the biomass of fauna. The hypothesis that an increase in mesofauna diversity has a negative effect on functional decomposition parameters could be explained by a decrease in several species within the microflora and consequently a decrease in compensatory activity within the microflora community with respect to decomposition processes. This argument is based on several works concerning feeding preferences of mesofauna, which demonstrated that several Collembola species may prefer to feed on specific bacteria or fungi (Chen et al. 1995; McMillan 1976; Shaw 1988; Thimm and Larink 1995). In this case, the possible compensation of activity of one microbial species by another would be less probable with a pool of mesofauna species grazing on various microbial species than with only one mesofauna species grazing only on one microbial species. In contrast, if we assume that many mesofauna species are polyphagous, they are able to adapt their diet to trophic resources induced by ecophysiological and biotic constraints like competition or predation. Thus, in this last hypothesis, if the number of constraints increases, which is the case in the more diversified mesocosms, the diversification of diets should also increase, as species would have to choose alternative feeding resources. Furthermore, the different species present in the mesocosms have habitat preferences: $E$. crypticus and $M$. macrochaeta prefer the true soil, whereas $H$. assimilis and $I$. prasinus are typically epigeic. Consequently more diverse habitats are probably colonised by a diversified community rather than by only one mesofauna species. Finally the increase in the use of ecological niches could limit the development of microflora and their primary decomposition activity. Thus, we agree with Ekschmitt and Griffiths (1998), who estimate that the major effect of species richness appears to be the reduction of functional gaps in time and space. However, we must note that after 30 days, due to the additive design of the experiment, total Collembola biomass was greater in multispecies treatments compared to the single species one. It is thus possible that the greater biomass in the multispecies mesocosms compared to the single one at this sampling date explained differences concerning functional decomposition parameters observed after 60 , 90 or 120 days. To test this, comparisons between additive and substitutive design (same total abundance of animals for each level of diversity) experiments should be carried out. However, we can expect two consequences from our observations. First, mesofauna species-specific interactions have to be taken into account in the understanding of decomposition processes. Second, the mesofauna species composition (the identity of the species), and not only the species richness (the number of species), might have an effect on decomposition processes. The same conclusions have been found concerning relations between plant diversity and ecosystem productivity (Hector et al. 1999). Few studies, however, have elucidated the links between diversity and function. In field mesocosms in a spruce forest soil, Vedder et al. (1996) noticed that faunal complexity caused an increase in the $\mathrm{N}$ turnover rate but they could not separate mesofauna and macrofauna effects. In manipulated complex biodiversity experiments, including different plant, herbivores and soil fauna communities, Naeem et al. (1994), observed an effect of biodiversity on organic matter decomposition. However only a short-term effect was observed and not in any consistent way. In recent microcosm experiments, Tuomainen et al. (2000) concluded that the functioning of soil ecosystems, at least with respect to plant growth, was quite independent of its species diversity.

On the other hand, there is a clear tendency for a predator impact on detritivorous species with consequences for the fungal biomass and finally for the functional decomposition parameters. Thus results show trends of a larger fungal biomass and a significant increase in $\mathrm{N}$ mineralisation processes in multispecies mesocosms containing H. aculeifer (PRED), compared to those without (DET). These results suggest top-down control by predators on organic matter decomposition processes. Top-down control has been used as an explanation in several studies. Thus, Santos et al. (1981) demonstrated that predatory mites could affect the decomposition of buried litter by regulating the population size of nematode bacterial grazers. Setälä et al. (1998) observed that predators could reduce primary production and plant $\mathrm{N}$ accumulation. Hedlund and Sjögren-Öhrn (2000) observed a cascade effect too, in this case that of the presence of predators on fungal biomass, while other experiments did not show any cascading effects (Mikola and Setälä 1998a).

Acknowledgements This work was supported by the European Science Foundation Programme on Linking Community and Ecosystem Ecology (LinkEcol) and the Centre for Biological Processes in Contaminated Soils and Sediments (BIOPRO). We would like to thank Zdenek Gavor, Karen Kjaer Jacobsen, Elin Jørgensen, Trine G. Sørensen, Anni Christiansen, Egon Frandsen, and Jørgen M. Nielsen for their excellent technical assistance, as well as Lene Birks $\emptyset$ for her professional efficiency. This work is dedicated to the memory of Nicole Poinsot-Balaguer. 


\section{References}

Bermingham S, Maltby L, Cooke RC (1995) A critical assessment of the validity of ergosterol as an indicator of fungal biomass. Mycol Res 99:479-484

Booth RG, Anderson JM (1979) The influence of fungal food quality on the growth and fecundity of Folsomia candida (Collembola: Isotomidae). Oecologia 38:317-323

Chen B, Snider RJ, Snider RM (1995) Food preference and effects of food type on the life history of some soil Collembola. Pedobiologia 39:496-505

Christiansen K (1971) Factors affecting predation on Collembola by various arthropods. Ann Speleo 26:97-106

Cortet J, Gillon D, Joffre R, Ourcival JM, Poinsot-Balaguer N (2002) Effects of pesticides on organic matter recycling and microarthropods in a maize field: use and discussion of the litter-bag methodology. Eur J Soil Biol 38:261-265

Djajakirana G, Joergensen RG, Meyer B (1996) Ergosterol and microbial biomass relationship in soil. Biol Fertil Soil 22:299304

Domsch K, Gam W (1993) compendium of soil Fungi, vol 1. IHW, Germany

Ekschmitt K, Griffiths BS (1998) Soil biodiversity and its implications for ecosystem functioning in a heterogeneous and variable environment. Appl Soil Ecol 10:201-215

Gessner MO, Schmitt AL (1996) Use of solid-phase extraction to determine ergosterol concentrations in plant tissue colonized by fungi. Appl Environ Microb 62:415-419

Hanlon RDG, Anderson JM (1979) The effects of Collembola grazing on microbial activity in decomposing leaf litter. Oecologia 36:93-99

Hector A, Schmid B, Beierkuhnlein C, Caldeira MC, Diemer M, Dimitrakopoulos PG, Finn JA, Freitas H, Giller PS, Good J, Harris R, Högberg P, Huss-Danell K, Joshi J, Jumpponen A, Körner C, Leadley PW, Loreau M, Minns A, Mulder CPH, O'Donovan G, Otway SJ, Pereira JS, Prinz A, Read DJ, Scherer-Lorenzen M, Schulze ED, Siamantziouras ASD, Spehn EM, Terry AC, Troumbis AY, Woodward FI, Yachi S, Lawton JH (1999) Plant diversity and productivity experiments in European grasslands. Science 286:1123-1127

Hedlund K, Sjögren-Öhrn M (2000) Tritrophic interactions in a soil community enhance decomposition rates. Oikos 88:585-591

Hopkin SP (1997) Biology of the springtails (Insecta: Collembola). Oxford University Press, New York

Huhta V, Wright DH Coleman DC (1989) Characteristics of defaunated soil. I. A comparison of three techniques applied to two different forest soils. Pedobiologia 33:417-426

Huston MA, Aarssen LW, Austin MP, Cade BS, Fridley JD, Garnier E, Grime JP, Hodgson J, Lauenroth WK, Thompson K, Vandermeer JH, Wardle DA (2000) No consistent effect of plant diversity on productivity. Science 289:1255

Jensen UB, Elmholt S, Labouriau R (2000) Distribution of ergosterol in organically and conventionally cultivated agricultural soils. Biol Agric Hortic 18:113-125

Joffre R, Ågren G (2001) From plant to soil: litter production and decomposition. In: Roy J, Saugier B, Mooney HA (eds) Global terrestrial productivity: past, present, future. Academic Press, San Diego, Calif., pp 83-99

Krogh PH (1995) Effects of pesticides on the reproduction of Hypoaspis aculeifer (Gamasida: Laelapidae) in the laboratory. Acta Zool Fenn 196:333-337

Lavelle P, Blanchart E, Martin A, Spain AV, Toutain F, Barois I, Schaefer R (1993) A hierarchical model for decomposition in terrestrial ecosystems: application to soils of the humid tropics. Biotropica 25:130-150

Martens H, Jensen SA (1982) Partial least squares regression: a new two-stage NIR calibration method. In: Holas J, Kratchovil R (eds) Proceedings of the 7th World Cereal Bread Congress. Elsevier, Amsterdam, pp 607-647

McMillan JH (1976) Laboratory observations on the food preference of Onychiurus armatus (Tullb.) Gisin (Collembola, Family Onychiuridae). Rev Ecol Biol Sol 13:353-364
Mebes K, Filser J (1998) Does the species composition of Collembola affect nitrogen turnover? Appl Soil Ecol 9:241-247

Mercer EI (1984) The biosynthesis of ergosterol. Pestic Sci 15:133155

Mikola J, Setälä H (1998a) No evidence of trophic cascades in experimental microbial-based soil food web. Ecology 79:153164

Mikola J, Setälä H (1998b) Productivity and trophic-level biomasses in a microbial-based soil food web. Oikos 82:158-168

Möttönen M, Järvinen E, Hokkanen TJ, Kuuluvainen T, Ohtonen R (1999) Spatial distribution of soil ergosterol in the organic layer of a mature Scots pine (Pinus sylvestris L.) forest. Soil Biol Biochem 31:503-516

Naeem S, Thompson LJ, Lawler SP, Lawton JH, Woodfin RM (1994) Declining biodiversity can alter the performance of ecosystems. Nature 368:734-737

Pasanen A, Yli-Pietilä K, Pasanen P, Kalliokoski P, Tarhanen J (1999) Ergosterol content in varoius fungal species and biocontaminated building materials. Appl Environ Microb 65:138-142

Petersen H (1975) Estimation of dry weight, fresh weight, and calorific content of various collembolan species. Pedobiologia $15: 222-243$

Petersen H, Luxton M (1982) A comparative analysis of soil fauna populations and their role in decomposition processes. Oikos 39:288-388

Santos PF, Phillips J, Whitford WG (1981) The role of mites and nematodes in early stages of buried litter decomposition in a desert. Ecology 62:664-669

Sardar MA, Murphy PW (1987) Feeding tests of grassland soil inhabiting gamasina predators. Acarologia 28:117-121

Setälä H, Haimi J, Huhta V (1988) A microcosm study on the respiration and weight remaining in birch litter and raw humus as influenced by soil fauna. Biol Fertil Soil 5:282-287

Setälä H, Laakso J, Mikola J, Huhta V (1998) Functional diversity of decomposer organisms in relation to primary production. Appl Soil Ecol 9:25-31

Setälä H, Tyynismaa M, Martikainen E, Huhta V (1991) Mineralization of $\mathrm{C}, \mathrm{N}$ and $\mathrm{P}$ in relation to decomposer community structure in coniferous forest soil. Pedobiologia 35:285-316

Shaw PJA (1988) A consistent hierarchy in the fungal feeding preferences of the Collembola Onychiurus armatus. Pedobiologia 31:179-187

Shenk JS, Westerhaus MO (1991a) Population definition, sample selection, and calibration procedures for near infrared reflectance spectroscopy. Crop Sci 31:469-474

Shenk JS, Westerhaus MO (1991b) ISI-NIRS-2. Software for nearinfrared instruments. Infrasoft International

Siepel H, Maaskamp F (1994) Mites of different feeding guilds affect decomposition of organic matter. Soil Biol Biochem 26:1389-1394

Stahl PD, Parkin TB (1996) Relationship of soil ergosterol concentration and fungal biomass. Soil Biol Biochem 28:847855

Takeda H (1979) On the extraction process and efficiency of MacFadyen's high gradient extractor. Pedobiologia 19:106112

Theenhaus A, Scheu S, Schaeffer M (1999) Contramensal interactions between two collembolan species: effects on population development and on soil processes. Funct Ecol 13:238-246

Thimm T, Larink O (1995) Grazing preferences of some Collembola for endomycorrhizal fungi. Biol Fertil Soil 19:266-268

Tuomainen M, Setälä H, Haimi J, Pennanen T, Fritze H (2000) Is species diversity really important? In: The XIIIth International Colloquium On Soil Zoology, Ceske Budejovice

Vedder B, Kampichler C, Bachmann G, Bruckner A, Kandeler E (1996) Impact of faunal complexity on microbial biomass and $\mathrm{N}$ turnover in field mesocosms from a spruce forest soil. Biol Fertil Soil 22:22-30

Verhoef HA (1996) The role of soil microcosms in the study of ecosystem processes. Ecology 77:685-690 
Verhoef HA, Prast JE, Verweij RA (1988) Relative importance of fungi and algae in the diet and nitrogen nutrition of Orchesella cincta (L.) and Tomocerus minor (Lubbock) (Collembola). Funct Ecol 2:195-201

Wardle DA, Giller K (1996) The quest for a contemporary ecological dimension to soil biology — discussion. Soil Biol Biochem 28:1549-1554
Wardle DA, Lavelle P (1997) Linkages between soil biota, plant litter quality and decomposition. In: Giller KE, Cadisch G (eds) Driven by Nature - plant litter quality and decomposition. CAB International, Wallingford, pp 107-124

Young JC (1995) Microwave-assisted extraction of the fungal metabolite ergosterol and total fatty acids. J Agric Food Chem 43:2904-2910 